\title{
Sociolinguistic Aspects and Language Contact: Evidence from Francoprovençal of Apulia
}

\author{
Carmela Perta \\ Professor of Sociolinguistics, Department of Languages, Literatures and \\ Cultures, G. d'Annunzio University, Chieti-Pescara, Italy \\ cperta@unich.it
}

\begin{abstract}
The aim of this paper is to investigate two Francoprovençal speaking communities in the Italian region of Apulia, Faeto and Celle di St. Vito. Despite the regional neighborhood of the two towns, and their common isolation from other Francoprovençal speaking communities, their sociolinguistic conditions are deeply different. They differ in reference to the functional distribution of the languages of the repertoire and speakers' language uses, and in reference to the degree of 'permeability' of Francoprovençal varieties towards Italian and its dialects. The repertoire composition and the relationship between the codes have a key role both for minority language maintenance and for language contact processes. In this perspective, I analyse some language contact phenomena in a sample of speakers discourse. I report correlations between the choice of different code-mixing strategies and three sociolinguistic variables (age, sex and village), but not with occupation.
\end{abstract}

\section{Keywords}

contact - discourse - Faetar - Cellese

\section{Introduction}

Language endangerment is usually not analysed on the basis of language contact present in speakers' discourse, commonly because scholars' attention has been primarily pointed at language change occurring in a particular structural

(C) CARMELA PERTA, 2020 | DOI:10.1163/19552629-bja10011

This is an open access article distributed under the terms of the prevailing CC-BY-NC license at the time of publication. 
level, rather than at 'superficial' phenomena such as code-switching.' In addition, an approach focusing on the correlation among contact phenomena and a particular sociolinguistic situation of an endangered speech community is rather infrequent in the literature.

In this perspective, the focus of this study is on Francoprovençal, an endangered language which is native to a wedge-shaped region expanding eastward from Lyon, France, through the Alps into western Switzerland and into the Northern Italian regions of Valle d'Aosta and Piedmonte and finally into two villages of Southern Italy. The aim of this study is to analyse language contact in the two Francoprovençal speaking communities of the South - Faeto and Celle di St. Vito - in relation to their sociolinguistic situation. I show whether and how a given sociolinguistic context has an impact on particular bilinguals' discourse strategies.

\subsection{The Communities}

The villages are isolated, located high in the Apenine Mountains (Faeto is 866 high and Celle di St. Vito 735), over an hour's drive from any city or train station (see Fig. 1). During the 2oth century Faeto and Celle di St. Vito underwent repeated waves of migration towards Northern Italy and America, with a decrease from 4569 (census 1911) to 685 inhabitants (census 2005) in Faeto, and from 1050 (census 1911) to 223 inhabitants (census 2005) in Celle; the result is that the majority of people living in the villages belong to the older generation.

The history of their migration is unclear, indeed there are conflicting accounts as concerns the origin of the two communities. It is not certain whether these groups, whose settlement has been established to be between the late of 1200 s and 1500s, ${ }^{2}$ were Angevins or Waldenses. According to the first account, a group from Provence was sent by Carlo d'Angiò in order to repopulate the area of Lucera (province of Foggia) and they finally settled near Torrente Celone where the two villages are; whereas, according to the second account, a Waldenses group escaped from Provence for religion reasons and settled in the area of Torrente Celone. However, it is for their origin linked to Provence that most of the community members declare they speak Provençal rather than Francoprovençal. ${ }^{3}$ It was only in 1888 that Suchier, on the basis of the language used in a brief novel (Papanti, 1875), established that Faeto and Celle varieties belong to the Francoprovençal group, rather than to the Provençal one.

1 As Dal Negro (2005) pointed out, this might be due to the typology of data collected in these settings, usually translations, which are not suitable for code-switching analyses.

2 Sobrero (1974), Telmon (1994).

3 Cf. Perta (2008a) and Perta (2010). 


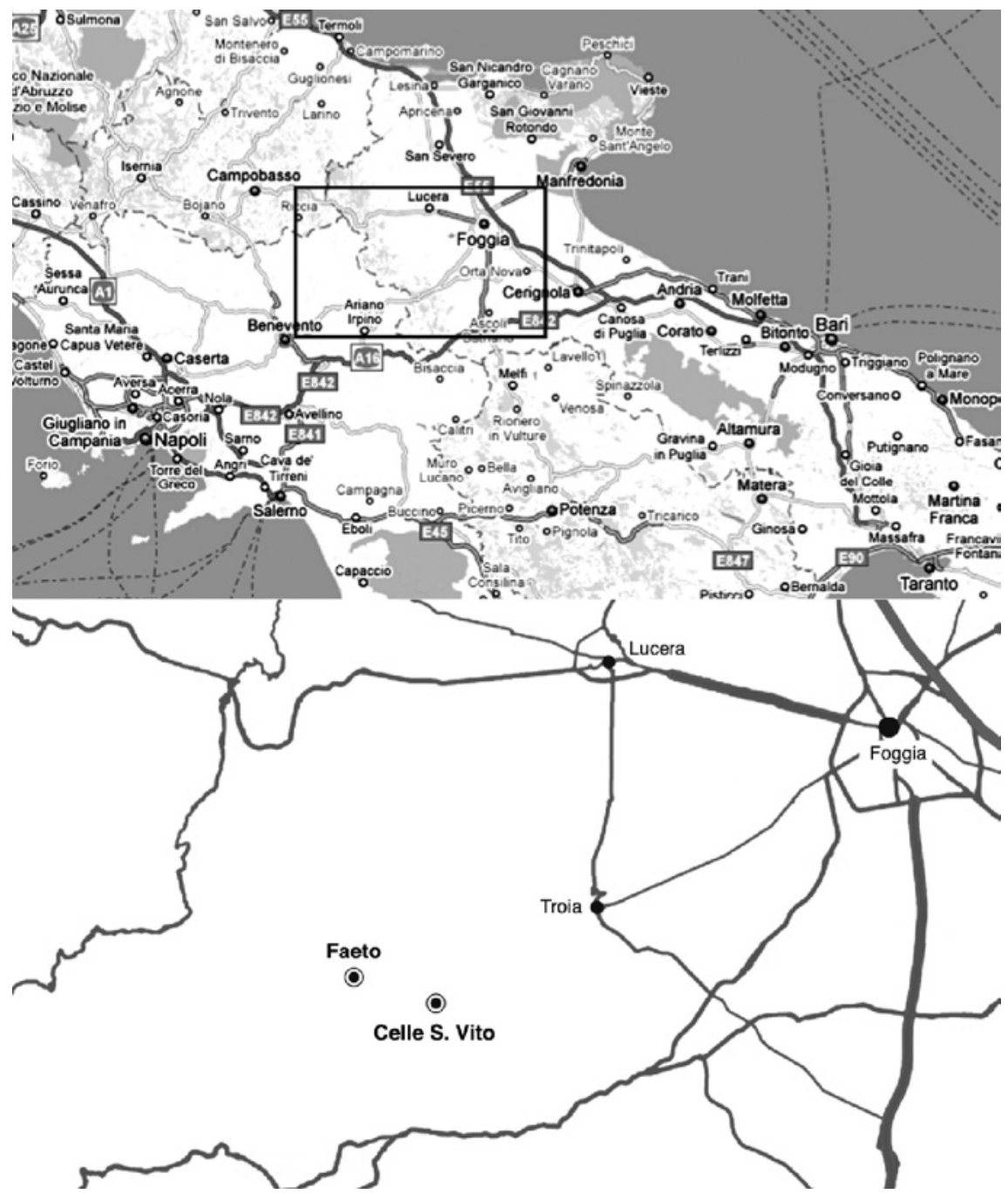

FIGURE 1 Faeto and Celle di St. Vito

A local Francoprovençal literary tradition does not exist, and grammars of the minority language (Morosi, 1890-1892; Kattenbusch, 1982; Nagy, 2000; SLF, $2007 \mathrm{~b}$ ), as well as studies on the lexicon are few (Minichelli, 1994; SLF, 2005; SLF, 2007a).

\subsection{The Local Varieties of Francoprovençal}

Since the contact situation between Faetar and Cellese, the ways the local Francoprovençal varieties are called, and other Apulian dialects has existed for some 700 years, phonetically and lexically these varieties present numerous 
analogies with the surrounding Apulian dialects, even though particular features of grammar remain distinct from Italian and its dialects. For example, Faetar and Cellese have a negation marker pas which follows the main verb, while Italian has the preverbal marker non. Moreover, Italian is a pro-drop language, while these varieties have a variable system: double subject pronouns are possible, at least one subject pronoun is required in many contexts, and a null subject pronoun in some instances. ${ }^{4}$ Verbal suffixes, determiners and plural morphemes remain distinct from corresponding Italian forms (Nagy, 2000).

Phonologically, the system echoes that of Italian and its close regional Italian varieties. Similar phonotactic contraints exist, even though coda position clusters are frequent in Faetar and Cellese due to the frequent deletion of posttonic vowels. Furthermore, the presence of the reduced vowel shwa - which often appears in unstressed syllables and phonological role is uncertain ${ }^{5}-$ is similar to the surrounding regional Italian varieties. Some evidence of structural borrowing from Italian into Faetar and Cellese is seen in the presence of geminate consonants, a distinctive phonological structure of Italian, ${ }^{6}$ besides cases of rafforzamento fonosintattico. ${ }^{7}$

\subsection{Diffusion of Faetar and Cellese}

In Faeto the minority language is largely used by the population: $92 \%$ of the informants, belonging to all age groups, declare that they speak Faetar fluently. Only a low rate of respondants (8\%), a small part of younger generation state they know Faetar, but are not fluent in it (Perta, 2008a). Moreover, none of the social variables - age, sex, education and occupation - appear to be correlated to the speakers' degree of competence in Faetar. According to what speakers state, excluding any local Italian dialect, two languages are used by the community: (Apulian regional) Italian and Faetar. Their functional distribution is balanced, since Faetar is used more than Italian in all informal settings, while in formal contexts, Italian is commonly used more than Faetar, even though

4 It is worth noting that this last variant in Faetar and Cellese is common to other Francoprovençal varieties as well. For this structural feature see AIS maps (1928-1940: \#512, \#887), Nagy and Heap (1998). In Perta (2015b) it is shown that bilingual speakers use this variable structural feature to perform their minority identity.

5 Cf. Nagy (2001).

6 Since Francoprovençal does not have contrastive length in its consonantal system, the Faetar and Cellese pattern should be attributed to language contact (Nagy, 1994).

7 According to it, Faetar and Cellese exhibit a process of word-initial consonant lengthening following a word-final stress vowel. For the analysis of raddoppiamento fonosintattico in Faetar see Nagy (2001). 
the minority variety is trying to extend itself also to formal domains. ${ }^{8}$ However, recent data (Perta, 2016) show that in adult and younger generation's discourse an Apulian dialect emerges in competition with Faetar.

According to the above mentioned survey results, $56 \%$ of the informants are actively competent in Cellese, $22 \%$ state they know it passively, and $22 \%$ do not know the minority language at all. Age, education and occupation are statistically significant variables, which determine the degree of speakers' competence in Cellese. In other words, loyalty towards the minority language is associated with elderly, rural areas, and primary sector employment. The local variety of Francoprovençal is not commonly used by all the community, to the point that the repertoire of most of younger speakers is based on Italian and its regional dialect, both used according to the formality of the situation. For adult speakers, the use of Cellese increases and the use of Apulian dialect decreases as the speakers' age increases. Hence, in Celle the languages spoken by the community are (regional) Italian, Apulian dialect and Cellese. Italian, the High variety, is used also in informal settings as to determine a situation of dilalìa. ${ }^{9}$ The other languages, competing in the functional space of the Low variety, create a dangerous situation for the minority language maintenance, since Apulian dialect is gaining more domains and functions than Cellese.

\subsection{Language Contact and Sociolinguistic Context}

Native speakers of Faetar and Cellese frequently claim that the younger generation has lost almost all native vocabulary due to Italian influence, and therefore the local varieties of Francoprovençal are disappearing (Nagy, 2000; Nagy, 2011; Perta, 2008a). Indeed, it is commonly argued that lexicon is the most variable part of the language, particularly in language contact situations, ${ }^{10}$ even in cases of language maintenance. However, previous studies (Perta, 2012; Perta, 2015a) focussing on the variable presence of Italian/Apulian dialect lexicon in speakers' discourse in Faetar and Cellese, demonstrate that lexical change, although a real phenomenon, is not presently happening in a severe

8 The presence of Faetar in formal settings is not tangible: since the approval of Law 482/1999, Faetar is one of the officially recognised minority languages of Italy. Local authorities and planners which have legal instruments are carrying out several operations to strengthen their language position and to promote it in new settings. The resulting codification gave birth to an exterior and slightly alien system, according to the speakers' reactions, since they feel this language does not reflect what they actually use (see Perta, 2008b).

9 Dilalìa is a diachronic evolution of diglossia: High Language is used also in informal domains and the functional space of Low Language is reduced (cf. Berruto, 1995).

10 Cf. Thomason and Kaufman (1988). 
way, affecting the basic vocabulary, and is not detected in an age-graded synchronic analysis. We would expect that the insertion of Italian/Apulian dialect lexical material affects more a situation where the ethnic language is declining, as in Celle di St. Vito, rather than a situation where the minority language is healthy, as in Faeto.

However, besides showing a similar pattern in that no social factor is significant in explaining the variation in lexicon, the foreign material is balanced among the two villages. The different sociolinguistic situations do not seem to affect the degree of Italian lexical insertion in speakers' discourse in the minority dialects. One possible reason could be, following Nagy (2011) and confirming Chamber's intuition (1992), ${ }^{11}$ that there will be more evidence of change in the early stages of contact situation, because change would occur more rapidly. Faetar and Cellese have had contact with Italian for a long time: in the early stages of contact Italian lexical interference had proceeded fast, but now it advances slowly.

Since other studies are needed to understand whether the conclusion reached for the lexicon could be extended to other language areas, my aim is to analyse language contact phenomena present in speakers' discourse. I investigate bilinguals' discourse strategies and their correlation with sociolinguistic variables, both in situation of minority language shift, as in Celle di St. Vito, and in situation of minority language maintenance, as in Faeto.

\subsection{Discourse Strategies in Bilingual Speech}

According to previous studies, language contact phenomena at the discourse level could be referred to as prototypes in a continuum (Berruto, 2009), where alternation of code and fused lect are the opposite terminals (Berruto, 2009; Auer, 1999). From alternation of code, mostly due to change of interlocutor, ${ }^{12}$ we go to intersential code-switching, then reaching code-mixing, ${ }^{13}$ finally to hybrid forms (Berruto, 2005). Moreover, in some cases it is possible to obtain what Auer (1999) calls a fused lect, the starting point for the formation of a

11 Chambers (1992: 680) affirms that change happens more rapidly at the beginning of the acquisition process than later at the micro-level, whereas Nagy (2011) extends the principle to the whole community.

12 Since alternation of code depends on the typology of speech event and on change of interlocutor, this phenomenon is to be analysed from a functional-pragmatic point of view.

13 There are conflicting accounts about the necessity of distinguishing intersential and intrasential code-switching. However, it seems appropriate to maintain this opposition, that is among code-switching and code-mixing, since the former process has functionalpragmatic value, rather than the latter. Hence the level of analysis of code-switching phenomena is pragmatics and textual linguistics, whereas code-mixing phenomena could be analysed from a syntactic point of view (cf. Berruto, 2009). 
mixed language, a sort of 'frozen' mixing, where phenomena of speakers' discourse start establishing in the language system. In other words, a fused lect presupposes code-mixing which implies code-switching, which implies alternation of code, while on the other way round, it is possible to have alternation of code phenomena without any code-switching. Comparing different minority languages present in Italy, it was demonstrated (Berruto, 2009) that this implication in synchrony is reflected in diachrony as well: first alternation of code, then switching, then mixing and in some cases hybrid forms and fused lect. In conclusion, there is a first stage (alternation of code) where the two languages are completely separated, a second one implies a situation of more and more interpenetration of the languages (from switching to mixing), even though speakers can choose to use one language rather the other, finally arriving in a situation where their choice is reduced, to the point that lexical elements from the other language start being compulsory in use. In other words, from phenomena at level of speaker's discourse we pass to phenomena at the level of the language system.

Comparing different minority communities present in Italy, Dal Negro (2005) individuated the following bilinguals' discourse strategies; they are listed from a higher to a lower degree of knowledge of the minority language:

1. Discourse with a high frequency of alternation of code, generally caused by change of interlocutor, with a direct return to the minority language;

2. Discourse with a high frequency of intersential code-switching, commonly used to meet either conversational or textual functions;

3. Discourse with a high frequency of code-mixing in the form of insertion and alternation. ${ }^{14}$

In the case of Faeto and Celle di St. Vito, the applicability of the above scale of discourse strategies is investigated: firstly particular strategies in relation to the degree of speakers' competence in the minority language are identified, also by correlating bilinguals' strategies to sociolinguistic variables; speakers discourse strategies in both communities are compared, in order to explore whether and how the sociolinguistic context of the community affects speakers' discourse.

14 Alternation - where segments from one language are alternated with segments from another - entails a lower degree of mix between the languages, than the process of insertion, a phenomenon where one language provides the grammatical structure and material from another language is inserted into this structure (Muysken, 2000). Moreover, in particular conditions, insertion would entail to the development of a fused lect. 


\subsection{Methodology}

The sample is constituted by forty-eight speakers split equally between Faeto and Celle di St. Vito and equally distributed between sex. In each town respondants are divided into four age groups, and segmented according to their occupations (Table 1).

TABLE 1 Sample of Faeto and Celle di St. Vito

\section{Occupation}

Age

Group Village

Student Employee Unemployed Housewife Total

\begin{tabular}{|c|c|c|c|c|c|c|}
\hline \multirow[t]{2}{*}{$9-20$} & Faeto & ${ }_{1} \mathrm{M},{ }_{3} \mathrm{~F}$ & & $2 \mathrm{M}$ & & $3^{\mathrm{F}}, 3_{3 \mathrm{M}}$ \\
\hline & Celle di St. Vito & ${ }_{1} \mathrm{M},{ }_{3} \mathrm{~F}$ & & $2 \mathrm{M}$ & & $3^{\mathrm{F},} 3^{\mathrm{M}}$ \\
\hline \multirow[t]{2}{*}{$21-40$} & Faeto & & $3^{\mathrm{M}},{ }_{1} \mathrm{~F}$ & & $2 \mathrm{~F}$ & $3^{\mathrm{F}}, 3^{\mathrm{M}}$ \\
\hline & Celle di St. Vito & & $3^{\mathrm{M}},{ }_{1} \mathrm{~F}$ & & $2 \mathrm{~F}$ & $3^{\mathrm{F},} 3^{\mathrm{M}}$ \\
\hline \multirow[t]{2}{*}{$41-6 o$} & Faeto & & $2 \mathrm{M}, 1 \mathrm{~F}$ & $1 \mathrm{M}$ & $2 \mathrm{~F}$ & $3^{\mathrm{F}}, 3^{\mathrm{M}}$ \\
\hline & Celle di St. Vito & & $2 \mathrm{M}, 1 \mathrm{~F}$ & $1 \mathrm{M}$ & $2 \mathrm{~F}$ & $3^{\mathrm{F}}, 3^{\mathrm{M}}$ \\
\hline \multirow[t]{2}{*}{$61-85$} & Faeto & & $3^{\mathrm{M}, 1 \mathrm{~F}}$ & & $2 \mathrm{~F}$ & $3^{\mathrm{F}}, 3^{\mathrm{M}}$ \\
\hline & Celle di St. Vito & & $3^{\mathrm{M}}, 1 \mathrm{~F}$ & & $2 \mathrm{~F}$ & $3^{\mathrm{F}}, 3^{\mathrm{M}}$ \\
\hline
\end{tabular}

Speakers from each age group both in Faeto and Celle talked to each other in a group; their discourse was recorded by a speaker of the community, who hided the tape-recorder and did not take part into the conversation, in order not to alter the data. The first three utterances from each speaker were introduced in the analysis, to have the same amount of material for each informant; hence for each age group 18 utterances are examined here.

\subsection{Data Analysis}

Discourse strategies listed in Section 2 are the starting point for the classification of data. Utterances from each informant are divided according to the degree of sociolinguistic vitality ${ }^{15}$ of the minority language: 1 . safe, 2 . unsafe, 3 . severely endangered. ${ }^{16}$ Discourse is classified on the basis of eight variants of

15 The sociolinguistic vitality of a language is essentially based on the diffusion and use of the language in the community, and speakers' attitude towards it (Dressler, 2003; Berruto, 2011). For the vitality of Francoprovençal varieties in Apulia see Perta (2013).

16 They are 3 of the 9 criteria of UNEsco's scale for assessing the status and vitality of languages (Brenzinger et al., 2003). 
speakers' discourse. ${ }^{17}$ Strategies from 1 to 3 are used in cases where the minority language is 'safe', strategies 4 and 5 mirror an unsafe language context, strategies from 6 to 8 reflect a severely endangered language situation:

1. utterance in Faetar/Cellese;

2. utterance with alternation of code:

(1)

sette gli- ̀̀ ma nije + sa figlje de Donàt

this-FEM S she- be-PRES 3 PER S my nephew + his daughter of Donato

(change of interlocutor) ++

$\begin{array}{lllllll}\text { Mariangela } & \text { questa } & \text { è } & \text { la } & \text { mamma } & \text { di } & \text { Anna } \\ \text { Mariangela } & \text { this } & \text { be-PRES 3 PERS } & \text { the } & \text { mother } & \text { of } & \text { Anna }\end{array}$

'This is my nephew + Donato's daughter + Mariangela this is Anna's mother';

3. utterance with code-mixing, in the form of insertion of material from Italian/Apulian dialect into a Faetar/Cellese morpho-syntactic frame:18

$\begin{array}{llllll}\text { il } & \text { materiale } & t e & l & \grave{a} & \text { métte } \\ \text { The } & \text { material } & \text { you WEAK PERS PRON 2 PERS } & \text { it } & \text { must-2 PER S } & \text { put-INF }\end{array}$ ti sélle $i$ métte la fattije

You-STRONG PERS PRON 2 PER S that-MAS S he put-PRES 3 PER S the-FEM $S$ work

'You should provide the material he does the work';

4. utterance with code-switching:

(3)

gi $m^{\prime} \quad$ é pettà do l' éja frésche

I myself must-PRES 1 PER S paint-INF with the-FEM S water fresh con l' acqua fresca $\mathrm{e}$ sono sempre bella with the-FEM $S$ water fresh and be-PRES 1 PER S always beautiful

'I should paint myself with fresh water with fresh water and (I) am always beautiful';

17 In the examples Faetar and Cellese are reported in italics, while Italian and Apulian dialect in bold.

18 I, a native speaker from Apulia, decided whether a word belongs to Italian/Apulian dialect or not. 
5. utterance with code-mixing, in the form of alternation:

(4)

$\begin{array}{lllll}\text { ma Maria }+ \text { gli ést } & \text { zèn con te ? } \\ \text { but Maria }+ \text { she be-PRES 3 PER S togheter with you ? }\end{array}$

'[...] but is Maria with you?'

6. utterance with code-mixing, in the form of insertion of Faetar/Cellese lexical material into an Italian/Apulian dialect morpho-syntactic frame: (5)

\begin{tabular}{llllll} 
abbiamo & \multicolumn{1}{l}{ levato } & la & roba & abbàsce \\
have-PRES 1 PER P & remove-PAST PART & the- FEM S & thing & downstairs \\
+ & per & questo & sono & venuta & \\
+ & for & this-MAS S & be-PRES 1 PER S & come-PAST PART
\end{tabular}

'I removed the things from downstairs I came for this reason';

7. utterance with a hybrid form:

(6)



'I wonder what mumy is doing at home';

8. utterance in Italian/Apulian dialect only.

In cases of insertional code-mixing, data shows that only NPs from Italian or Apulian dialect were inserted, mostly content words, so as to make the phenomenon ambigous since it could belong either to mixing phenomena or borrowings. ${ }^{19}$ Here, the lexical elements resulted from contact will be treated as a phenomenon belonging to discourse level. ${ }^{20}$

The package sPss was used for calculating the statistical association between the eight variants of speakers' discourse strategies (dependent variables)

19 Setting a fixed line among contact phenomena occurring in the language system and those in discourse, particularly lexical elements is very complex (cf. Thomason, 2001; Halmari, 1997), whatever perspective is adopted (for example Sankoff et al., 1990; MyersScotton, 1993; Myers-Scotton, 2002). This is mostly due to the fact that native monolingual speakers in the minority language do not exist, hence it is not possible to apply one of the most valuable test to determine whether the lexical item is either a form of borrowing or a code-switching phenomenon (Thomason, 2001).

20 Even though I confirm the validity of the question, arguing on this matter would be out of the scope of this work. 
and their socio-demographic variables (independent variables). This association was calculated through a linear equation, which predicted the values of each dependent variable separately from knowledge of specified values of independent variables - i.e., predictors (age, sex, occupation, village). Each of them was tested in a separate model. The type of regression used, categorical regression, was chosen since it allows the analysis of both quantitative and qualitative data.

\subsection{The Results}

Most of the speakers use Faetar as the language of communication (34 utterances); in contrast there are 4 monolingual utterances in Italian/Dialect.

TABLE 2 Speakers' strategies in Faeto

Strategies Utterances

1 Monolingual Faetar

2 Alternation of code 34

3 Code-mixing (insertion Italian/Dialect) 8

4 Code-switching

5 Code-mixing (alternation)

6 Code-mixing (insertion Faetar)

7 Hybrid form

8 Monolingual Italian/Dialect

34
8
0
7
2
6
1
4

Looking at the distribution of the strategy according to speakers' age (Fig. 2), it results a hierarchy of the use of Faetar discourse: the number of utterances in the minority dialect increases as speaker's age. Moreover, as age diminishes, the mixture between the languages in speakers' discourse is deeper, to the point that the group of speakers ranging from 9 to 20 use all the strategies considered.
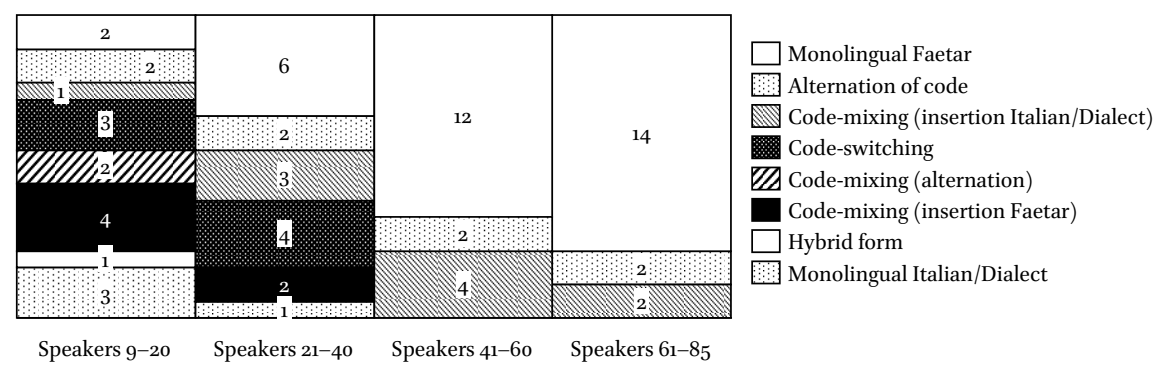

FIGURE 2 Discourse strategies and age in Faeto 
Through statistical analysis it results that age is strongly significant $(\mathrm{p}<.0001)$ in determining strategy 1 , that is the older the speaker is the more frequent discourse in Faetar (Beta $=.754$ ); however strategy 2 and 3 cannot be predicted by age $(\mathrm{p}>.5)$. Age is statistically significant $(\mathrm{p}<.5)$ in determining strategy 4 and is correlated negatively with this discourse strategy (Beta=-.449), hence the frequency of code-switching phenomena increases with the decreasing of speaker's age. A similar result is obtained in the case of strategy 5: age is a significant predictor in the variation of the use of mixing in the form of alternation $(\mathrm{p}<.5)$ and it is negatively correlated with this strategy (Beta=-.404); age behaves similarly in case of strategy $6(\mathrm{p}<.5$; Beta $=-.501)$. Whereas, for strategy 7 and 8, age is not a significant predictor in determining the variation $(\mathrm{p}>.5)$ in the use of hybrid forms and monolingual discourse in Italian/Dialect.

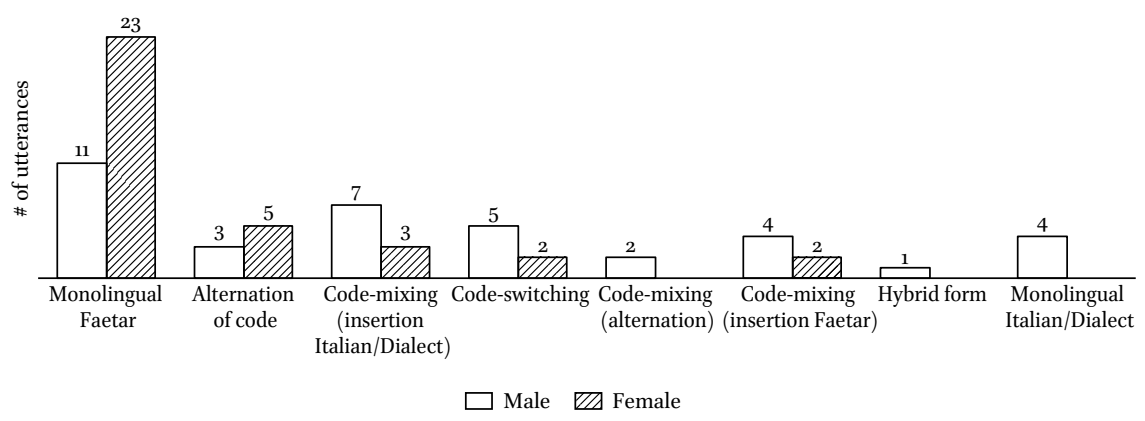

FIGURE 3 Discourse strategies and sex in Faeto

Sex is significant in predicting the variation in discourse in Faetar $(p<.5)$ : females are more likely than males to produce utterances in the minority dialect $($ Beta $=.481)$. Moreover sex is not a predictor for either of the other discourse strategies, as can be deduced from Fig. 3 which depicts a comparison of the distribution of bilinguals' strategies according to sex. Finally, occupation is not significant in determining variation in speakers' discourse strategies $(\mathrm{p}>.5)$.

The distribution of bilinguals' discourse strategies in Celle di St. Vito is shown in Table 3. The opposite strategies, monolingual utterances in Cellese (16) and utterances in Italian/Dialect (12) are almost balanced. In addition, the use of switching and mixing in the form of alternation records a high frequency (12). 
1 Monolingual Cellese

16

2 Alternation of code

5

3 Code-mixing (insertion Italian/Dialect)

5

4 Code-switching

12

5 Code-mixing (alternation)

12

6 Code-mixing (insertion Cellese)

8

7 Hybrid form

2

8 Monolingual Italian/Dialect

As the statistical analysis, age is significant in determining strategy 1 ( $\mathrm{p}<.00001)$ : Cellese is the language used for communication for older generation and its use decreases according to the speaker's age, to the point that speakers from younger generation do not use monolingual discourse in Cellese at all (see Fig. 4).
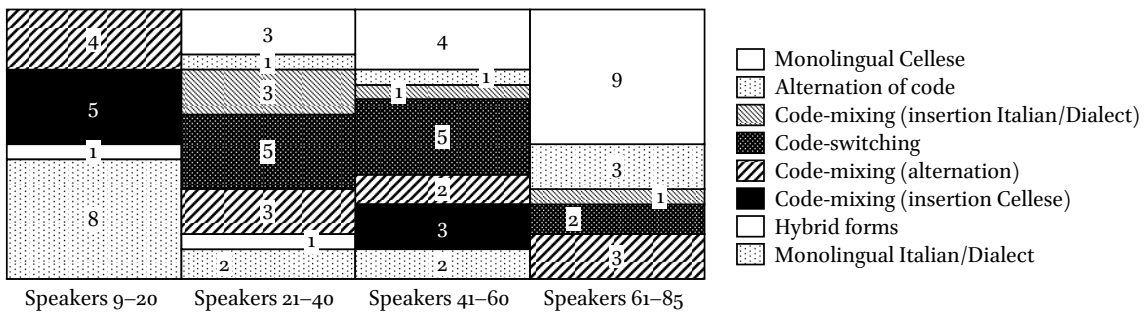

FIGURE 4 Discourse strategies and age in Celle di St. Vito

Age is a significant predictor for strategy $2(\mathrm{p}<.5$; Beta $=.412)$ as well; whereas the opposite trend is obtained in cases of strategy $6(\mathrm{p}<.5$; Beta=-.404), and 8 $(\mathrm{p}<.5$; Beta $=-.547)$, since these phenomena increase as speakers' age decreases. While, for strategy $3,4,5$ and 7 age does not make a statistically significant contribution ( $p>.5)$ in their variation. Sex is not a significant predictor in determining the variation in the typologies of discourse, apart from strategy 3 ( $\mathrm{p}<.5$; Beta $=.512$ ); hence in these cases, as is clear from Fig. 5, only females use this form of discourse strategy. Again occupation is not statistically significant in determining speakers' discourse strategies. 


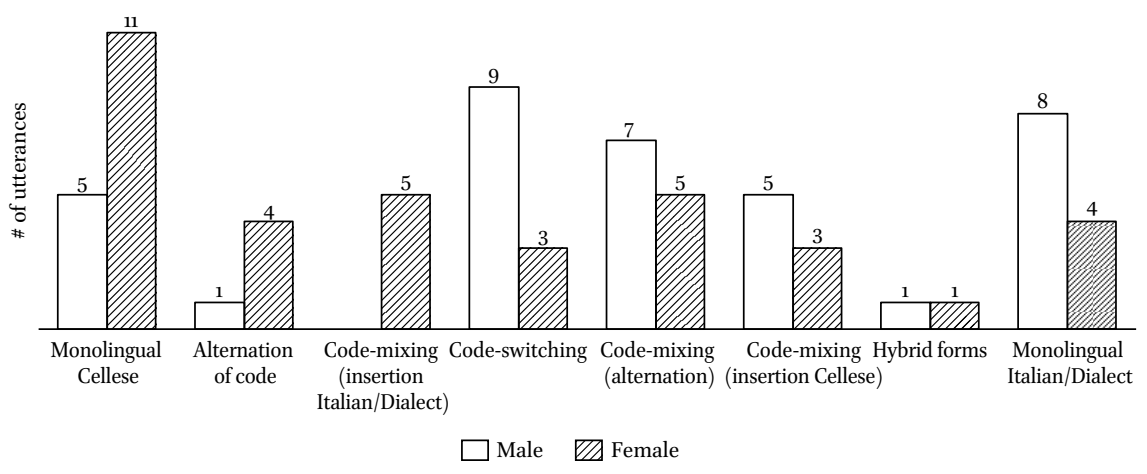

FIGURE 5 Discourse strategies and sex: in Celle di St. Vito

Comparing the distribution of each discourse strategy in Faeto and Celle, a double hierarchy emerges (see Fig. 6). The first three strategies show a higher score in Faeto than in Celle. From strategy 4 to 8, the trend is opposite: in Celle the score is higher than in Faeto. Moreover, while in Faeto there is a decreasing score from strategy 4 on, Celle speakers show an increasing trend. This result is statistically confirmed, since village is a significant predictor in explaining the variation in strategy $1(\mathrm{p}<.00001)$ and $8(\mathrm{p}<.0001)$ : Faeto is positively correlated to strategy 1 and inversely correlated to strategy 8.

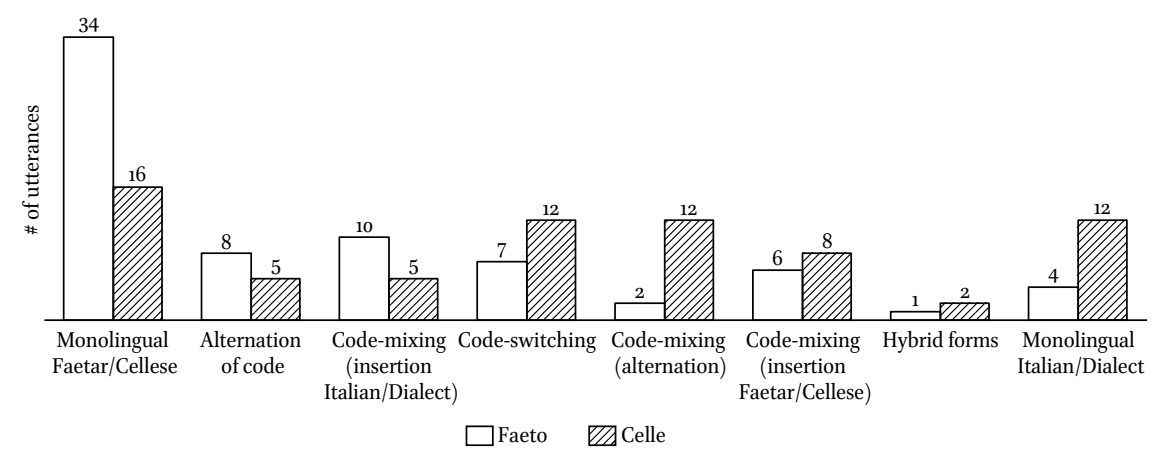

FIGURE 6 Bilinguals' discourse strategies in Faeto and Celle di St. Vito

\section{Conclusion}

In Faeto speakers' discourse strategies are similar among pairs of age groups. For speakers from 41 to 85 years old, Faetar is the language usually used among older and adult generations, most of the communication is monolingual in Faetar. Some exceptions exist: cases of alternation of code - that usually occur in situation of shift of the interlocutor - and examples of insertive mixing, 
where Italian content words are introduced in a Faetar frame. The other two groups, with speakers from 9 to 40 years old, show a similar pattern in discourse strategies: first of all the number of monolingual utterances in Faetar decreases and the use of all bilinguals' discourse strategies increases. In the case of the age group ranging from 21-40 there is a preference in the use of code-switching forms, along with cases of code-mixing phenomena, where lexical material from Faetar is inserted into an Italian/Apulian dialect frame. In the case of speakers from 9 to 20 years old, the number of utterances in Faetar decreases and the number of those in Italian/Apuilan dialect increases; moreover the number of mixing forms, where lexical material from Faetar into an Apulian dialect frame is inserted, are considerable.

In Celle speakers from older generation use different strategies in their bilingual discourse: apart from utterances in Cellese only and some examples of insertion of Italian content words into a Cellese frame, there are codeswitching and some alternant mixing phenomena. Speakers from 41-6o use all the strategies; moreover, the number of utterances in Cellese decreases as utterances in Italian/Dialect appear. Speakers from 21 to 40 years old show a similar pattern, besides the emergence of hybrid forms. Things are completely different in the case of the younger generation: there are no utterances in Cellese, or alternation of code, or insertion of Italian content words, or switching phenomena. Their discourse is mostly based on Italian/Dialect, besides cases of alternant and insertive mixing and a hybrid form.

Discourse strategies listed in Section 2.2 are not in complementary distribution, indeed they co-exist and overlap since minority sociolinguistic situations change rapidly; moreover they reflect different degree of speakers' competence in the minority language, having three prototypical situations. A first case is characterised by speakers fully competent in Faetar/Cellese: the minority language is used as the language of the communication, with the emerging of phenomena of alternation of code, commonly due to change of interlocutor, and forms of insertion of Italian lexical material, which could be the signal of particular lexical gaps. The second situation is characterised by speakers who are competent in both the languages, indeed there are various intersential switching forms usually with pragmatic values. Things are different when speakers' competence decreases: in their discourse there is a high frequency of code-switching forms, along with cases of alternant mixing, and mostly cases where lexical elements from the minority language appear into an Italian/ Apulian dialect morpho-syntactic frame. These are communicative situations usually involving younger speakers, who commonly use Italian/Apulian dialect as languages of the communication and cannot manage Faetar/Cellese well. In other words, it is possible to highlight a continuum of vitality of the minority dialects, starting from cases of ideal bilingualism, to settings of 
language shift where the minority language is still safe, since speakers have an individual repertoire with a good functional division among the codes, to situations where processes of language shift and decay are advanced.

Projecting the strategies used by speakers of Faetar and Cellese into the continuum of vitality of the minority dialects as outlined above, in Faeto bilinguals' strategies seem to reflect an ideal bilingualism shown by older and adult speakers, and safe cases of language shift revealed by younger generation; whereas in Celle the process of shift is more advanced, as shown by discourse strategies of both adult and mostly younger generation.

\section{References}

Auer, Peter. 1999. From codeswitching via language mixing to fused lects: Toward a dynamic typology of bilingual speech. International Journal of Bilingualism 3: 309-332.

Berruto, Gaetano. 1995. Fondamenti di sociolinguistica. Roma: Laterza.

Berruto, Gaetano. 2005. Dialect/standard convergence, mixing, and models of language contact: the case of Italy. In Peter Auer, Frans Hinskens and Paul Kerswill (eds.), Convergence and Divergence in European Languages, 81-96. Cambridge: Cambridge University Press.

Berruto, Gaetano. 2009. Confini tra sistemi, fenomenologia del contatto linguistico e modelli del code-switching. In Gabriele Iannaccaro and Vincenzo Matera (eds.), $L a$ lingua come cultura, 3-34. Torino: Utet Università.

Berruto, Gaetano. 2011. Considerazioni conclusive. In Bruno Moretti, Elena Maria Pandolfi and Matteo Casoni (eds.), Vitality of a minority language. Aspects and methodological issues, 289-302. Bellinzona: Osservatorio linguistico della Svizzers italiana.

Brenzinger, Matthias, Akira Yamamoto, Noriko Aikawa, Dmitri Koundiouba, Anahit Minasyan, Arienne Dwyer, Colette Grinevald, Michael Krauss, Osahito Miyaoka, Osamu Sakiyama, Rieks Smeets, and Ofelia Zepeda. 2003. Language vitality and endangerment. Paris: UNEsco Expert Meeting on Safeguarding Endangered Languages.

Chambers, Jack K. 1992. Dialect acquisition. Language 68, 4: 673-705.

Dal Negro, Silvia. 2005. Il codeswitching in contesti minoritari soggetti a regressione linguistica. Rivista di Linguistica 17.1: 157-178.

Dressler, Wolfang U. 2003. Dallo stadio di lingue minacciate allo stadio di lingue moribonde attraverso lo stadio di lingue decadenti: una catastrofe ecolinguistica considerata in una prospettiva costruttivista. In Giuliano Bernini, Pierluigi Cuzzolin, Piera Molinelli and Ada Valentini (eds.), Ecologia linguistica, 9-25. Roma: Bulzoni. 
Halmari, Helena. 1997. Government and Codeswitching. Explaining American Finnish. Amsterdam and Philadelphia: Benjamins.

Jaberg, Karl, Jakob Jud and Paul Scheuermeier. 1928-1940. AIs maps. Sprach-und Sachatlas Italiens und der Südschweiz. Zofingen, Switzerland: Ringier.

Kattenbusch, Dieter. 1982. Faeto und Celle: Frankoprovenzalishe Sprachkolonie in Süditalien. Ein Beitrag zur Soziolinguistik. In Christoph Schwarze (ed.), Italienische Sprachwissenschaft, 135-146. Saarbrücken: Tübingen.

Minichelli, Vincenzo. 1994. Dizionario francoprovenzale di Celle San Vito e Faeto. Alessandria: Edizioni dell'Orso.

Muysken, Peter. 2000. Bilingual Speech. A Typology of Code-mixing. Cambridge: Cambridge University Press.

Myers-Scotton, Carol. 1993. Duelling Languages. Grammatical Structure in Codeswitching. Oxford: Clarendon Press.

Myers-Scotton, Carol. 2002. Contact Linguistics. Oxford: Oxford University Press.

Morosi, Giuseppe. 1890-1892. Il dialetto francoprovenzale di Faeto e Celle nell'Italia meridionale. Archivio Glottologico Italiano, 33-75.

Nagy, Naomi. 1994. Language contact and change: Italian (?) geminates in Faetar. Belgian Journal of Linguistics 9: 11-112.

Nagy, Naomi. 2000. Faetar, Munich, Lincom Europa.

Nagy, Naomi, 2001. Stress and schwa in Faetar. In Lori Repetti (ed.), Italian Dialects and Phonological Theory (Current Issues in Linguistic Theory series), 239-254. Philadelphia. Benjamins.

Nagy, Naomi. 2011. Lexical change and language contact: Faetar in Italy and Canada. Journal of Sociolinguistics 15(3): 366-382.

Nagy, Naomi and David Heap. 1998. Francoprovençal null subject and constraint interaction. In M. Catherine Gruber, Derrick Higgins, Kenneth Olson and Tamara Wysocki (eds.), CLS 34 The Panels, 151-166. Chicago: Chicago Linguistic Society.

Papanti, Giovanni. 1875. I parlari italiani in Certaldo alla festa del V centenario di messer Giovanni Boccacci. Livorno.

Perta, Carmela. 2008a. Repertori e scelte linguistiche nelle comunità francoprovenzali della Puglia. Roma: Aracne.

Perta, Carmela. 2008b. Can language politics ensure languages survival? Evidence from Italy. Language and Linguistics Compass 2(6): 1216-1224.

Perta, Carmela. 2010. La varietà francoprovenzale della Puglia tra mantenimento e perdita linguistica. In Maria Iliescu, Heidi Siller-Runggaldier and Paul Danler (eds.), Actes du XXV Congrès International de Linguisique et de Philologie Romanes, Tome I, 215-222. Berlin and New York: de Gruyter.

Perta, Carmela. 2012. Sociolinguistic aspects and language contact. Lexical consequences in Francoprovençal settings. In Carmela Perta and Simone Ciccolone. 
Minority languages in Italy. Vitality, contact, and planning, 47-62. Saarbrücken: Lambert Academic Publishing.

Perta, Carmela. 2013. Languages in contact in minorities communities. The case of Francoprovençal in Italy. In Kelechukwu U. Ihemere (ed). Language Contact: A Multidimensional Perspective, 158-175. Cambridge, Cambridge Scholars Publishing.

Perta, Carmela. 2015a. Repertori comunitari e contatto lessicale: alcune riflessioni. In M. Grazia Busà and Sara Gesuato (eds.), Lingue e contesti. Studi in onore di Alberto $M$. Mioni, 673-687. Padova: CLEUP.

Perta, Carmela. 2015b. Contatto nel discorso in contesti alloglotti. Un esempio marcato dal francoprovenzale della Puglia. In Carlo Consani (ed.), Contatto interlinguistico fra presente e passato, 469-486. Milano: LED.

Perta, Carmela.2016.Esiti estremi di contatto in contestiminoritari.Un'esemplificazione. In Vincenzo Orioles and Raffaella Bombi (eds.), Lingue in contatto, 119-130. Roma: Bulzoni.

Sankoff, David, Shana Poplack and Swathi Vanniarajan. 1990. The case of the nonce loan in Tamil. Language Variation and Change 2(1): 71-101.

Sobrero, Alberto A. 1974. Il franco-provenzale in Capitanata: storia interna e storia esterna di una parlata alloglotta. In Alberto A. Sombrero (ed.), Dialetti diversi. Proposte per lo studio delle parlate alloglotte in Italia, 33-64. Lecce: Milella.

Sportello Linguistico Francoprovenzale (SLF). 2005. Glossario con rimario in francoprovenzale di Faeto. Foggia: L'Editrice.

Sportello Linguistico Francoprovenzale (SLF). 2007a. Dizionario francoprovenzaleitaliano, italiano-francoprovenzale di Faeto. Foggia: L'Editrice.

Sportello Linguistico Francoprovenzale (SLF). $2007 \mathrm{~b}$. Grammatica francoprovenzale di Faeto. Foggia: L'Editrice.

Telmon, Tullio. 1994. Presentazione. In Vincenzo Minichelli, (pages??). 1994.

Thomason, Sarah G. 2001. Language contact. An introduction. Edinburgh: Edinburgh University Press.

Thomason, Sarah and Terrence Kaufman. 1988. Language contact, creolization, and genetic linguistics. Berkley: University of California Press. 